\title{
Evaluating Risk Perception based on Gender Differences for Mountaineering Activity
}

\author{
Novie Susanto ${ }^{1, *}$, Susatyo Nugroho W.P ${ }^{1}$ and Ega Rizkiyah ${ }^{1}$ \\ ${ }^{1}$ Industrial Engineering Department, Faculty of Engineering, Diponegoro University, Semarang - Indonesia
}

\begin{abstract}
In average 26 death events in mountaineering per year for the time span from 2003 to 2012 is reported. The number of women dying during the mountaineering is significantly smaller than males (3.5 deaths male for one female death). This study aims to analyze the differences of risk perception based on gender and provide recommendations as education basic to prevent accidents in mountaineering. This study utilizes the Kruskal-Wallis test and the Delphi Method. A total of 200 mountaineer respondents (100 males and 100 females) participated in this study. The independent variable in this study was gender. The dependent variable was risk perception including perception toward the serious accident, perception toward the probability of accident event as well as anxiety level and perception of efficacy and self-efficacy. The study result showed that the risk perception of women is higher than men with significant difference (pvalue $=0.019)$. The recommendations from Delphi method result are by developing a positive mental attitude, showing about the risks that exist in nature, implementing Cognitive Behaviour Therapy (CBT) to raise awareness of the safety of ownself, following the climbing or mountaineer school, and using instructors to give lessons about safety in outdoor activities.
\end{abstract}

\section{Introduction}

Nowadays extreme sports activities in nature become the most popular activity. There are several activities that can be done in nature such as climbing the mountain. This is evidenced by the increasing number of mountaineers at all times. Increasing the number of mountain climbers can increase local revenue from the tourism sector, but it turns on some problems such as the increasing number of accident. Mountain is not a place that can be visited easily without good preparation because it can risk your life. According to Soule et al. [1] more than $30 \%$ of mountain-related deaths in France are mountain climbing, with an average death toll of 26 lives per year for the 2003 to 2012 timeframe. The possibility to die on women during the climb is significantly smaller than on men (3.5 deaths of men for one woman's death).

Some factors causing accidents that occur in the mountain according to Chamarro and Castro [2] are environmental events, equipment, medical events, errors, and time pressure. Mountain climbing is a high-risk activity. This is proven based on questionnaire results that have been distributed in the preliminary study to 258 respondents consisting of 120 male mountain climbers and 138 female mountain climbers. As many as $94 \%$ of all respondents stated that mountain climbing is an activity that has a high risk. Based on the experience of the respondents in mountain climbing, men climbed mountains on average eight times per year while women five times per year. The allegations suggest that this is because men's risk perception is lower than that of women in mountain climbing activities. As the research was done by Short, et al. [3] explains that men and women have different perceptions of risk as a whole in which men perceive lower risk than women in sports. According to Sitkin \& Pablo [4], risk perceptions concerning how individuals assess the risks inherent in certain situations. Even when individuals are exposed to the same activities and circumstances, it will result in different perceptions of risk. Some studies regarding risk perception were studied [5-9]

The purpose of this study was to analyze differences in risk perceptions of mountain climbing regarding gender and provide recommendations to prevent accidents on mountain climbing.

\section{Literature reviews}

\subsection{Perception}

Sunaryo [10] explains that perception is the process of receiving stimuli through the senses preceded by attention so that the individual can know, interpret, and appreciate about the observed, both outside and within the individual. There are two kinds of perception, namely: external perception and self-perception. External perception is the perception that occurs because of the stimuli that come from outside the individual, while self-perception is the perception that occurs because of the stimuli that come from within the individual self. In this case, the object is itself.

* Corresponding author: novie.susanto@ft.undip.ac.id 
Perception arises through the processes and factors that influence the perception. This is what causes each individual to have different interpretations, even though the objects seen are the same. According to Robbins and Judge [11], three factors affect one's perception are:

\subsubsection{Individual concemed}

Every individual sees something and tries to give an interpretation of the object being seen to be influenced by individual characteristics such as attitudes, personality, motives, interests, past experiences, and expectations.

\subsubsection{The goal of perception}

The characteristics of the perceptual target affect what the individual feels. Individuals who speak loudly will be more noticed than individuals who are quiet. This causes a person to tend to group people or similar events and separate them from other groups that are not similar.

\subsubsection{Situation}

Perception must be viewed contextually, which means the situation in which the perception arises should receive attention. The situation is a factor that contributes to the process of forming a person's perception.

\subsection{Risk perception}

Risk perception is a subjective assessment of the probability of a certain kind of probability of accidents occurring and to assess how much care it sees in a consequence [9]. Risk perceptions are influenced by psychological, socio-economic, and cultural processes [12].

Perceptions of risk or ability to differentiate risk associated with risk tolerance, or individual capacity to accept some risks. The official definition of risk is a measure of the probability and severity of an effect [9]. Inouye [13] explains that the inability to understand risk carefully can lead to a higher level of risk tolerance and can encourage the high-risk behavior.

\subsection{Mountaineering}

Mountaineering is an activity either rocks or icebergs climbing [14]. Pomfret [15] explains that mountain climbing is a tourism adventure and it is closely related to the power of emotional experience. Based on the previously mentioned description of the notion of risk perception and mountain climbing, it can be concluded that the perception of risk to mountain climbing is a subjective assessment of the probability of accident probability and to assess how much care in seeing a consequence arising on mountain climbing.

According to Chamarro \& Castro [2], there are some causes of accidents that occur on mountain climbing, i.e.,
1. Environmental Events are covering difficulties, weather conditions and environmental conditions.

2. Equipment including equipment condition, the quantity of equipment, and quality of equipment used, protective equipment, and knowledge of the use of such equipment.

3. Medical Events is fatigue triggered by the activity itself.

4. Errors including errors by omissions, errors by execution, and troubleshooting.

5. Time Pressure covering speed and rush.

In a study conducted by Demirhan et al. [9] on students at the University of Turkey with male respondents totalling 1479 women and 1259 men, it showed significant results on differences in gender-based risk perceptions in extreme sports. The goal of the study is to examine the perceived risks and appeal of extreme sports by gender. Extreme sports are land sports that consist of mountain climbing, rock climbing, trekking, orienteering, cave and cycling mountain bike. Water sports consisting of rowing, canoeing, surfing, sailing, water skiing, swimming, arum rafting and scuba diving. Winter sports consisting of skiing in the Alpine, skiing in the Nordic, skiing and snowboarding. Aero Sports which consists of parachutes, hang gliding, jumping cliffs, paragliding, and bungee jumping. Motor sports are consisting of carting, off road, rally, auto track, piste motor, cross motor, and motor track. The results of the study were consistent with the hypothesis of the study that men regard extreme sports as a less risky sport than women.

In contrast to research conducted by Monasterio [14], it stated that mountain climbers are populations that have different personality characteristics. The differences are not only about the characters that can define the personality of each mountaineer, but there are other factors namely the opportunities and access to climbing activities and rock climbing, peer influence, increased popularity, media spotlight and sports commercialization. So it can be concluded that the risk perception on each mountaineer depends on the personality of each climber.

In another study conducted by Harris \& Jenkins [16], it was explained that the male risk assessment is significantly seen from the severity of injuries suffered, while women assess a risk of susceptibility to any injury. This suggests that women may avoid risky situations that cause injury and men may avoid risky situations only if the injury suffered has been severe.

\subsection{Gender}

Gender is a set of characteristics and attributes that are socio culturally attached to men and women. The attached characteristics or attributes are created by the surrounding social or culture [17].

\subsection{Delphi method}

The Delphi method was used and popularized in the early 1960 s by RAND, a research institute in Santa 
Monica, California, USA. Delphi method is a method that is done by forming a group or group communication consisting of experts to discuss a problem. Generally the experts involved are experts with expertise in the subject matter being discussed [18].

\section{Methods}

The independent variable used in this research is gender. The dependent variable used in this study is the perception of risk in mountaineering. The hypothesis in this study is processed using Kruskall-Wallis test, with the aim to determine whether there is a significant difference in risk perception between men and women. The hypothesis in this research is as follows:

$\mathrm{H}_{0}$ : There is no significant difference in risk perception between men and women

$\mathrm{H}_{1}$ : There is a significant difference in risk perception between men and women

The basic decision in Kruskall-Wallis test is if the value of $\mathrm{P}$ Value $<0.05$ then it can be concluded that $\mathrm{H}_{1}$ accepted and $\mathrm{H}_{0}$ rejected. The questionnaires were distributed online to 200 mountaineers as respondents in this study. There were 100 respondents divided into 50 male and 50 female.

The questionnaire used in this study was designed based on adapted risk perception variables by Voetern [20] as seen in Table 1 .

Table 1. Variables used in the questionnaire [19]

\begin{tabular}{|c|l|l|}
\hline Variable & Sub variable & \multicolumn{1}{c|}{ Questionnaire } \\
\hline \multirow{5}{*}{$\begin{array}{c}\text { Risk perception } \\
\text { (RP) }\end{array}$} & $\begin{array}{l}\text { Perceptions of } \\
\text { the seriousness } \\
\text { of accidents }\end{array}$ & $\begin{array}{l}\text { RP1. The degree of } \\
\text { seriousness of accidents } \\
\text { that have occurred }\end{array}$ \\
\cline { 2 - 3 } & $\begin{array}{l}\text { Perception of the } \\
\text { possibility of } \\
\text { having an } \\
\text { accident and } \\
\text { anxiety levels } \\
\text { accident in the future }\end{array}$ \\
\cline { 2 - 3 } & $\begin{array}{l}\text { RP3. Opportunity to } \\
\text { experience accidents if } \\
\text { without precaution }\end{array}$ \\
\cline { 2 - 3 } & $\begin{array}{l}\text { RP4. Concern for } \\
\text { accidents }\end{array}$ \\
\cline { 2 - 3 } & $\begin{array}{l}\text { Perception of } \\
\text { *efficacy and } \\
* * \text { self-efficacy }\end{array}$ & $\begin{array}{l}\text { RP5. Response to } \\
\text { preventive measures }\end{array}$ \\
\cline { 2 - 3 } & $\begin{array}{l}\text { RP6. Willingness to } \\
\text { carry out preventive } \\
\text { measures }\end{array}$ \\
\hline
\end{tabular}

*) efficacy: Ability to perform the expected action **) self-efficacy: confidence that she/he can perform the expected action

In addition to the question of risk perception above, there were questions about the motivation to implement preventive measures and information needs [20]. Data processing on these questionnaires were performed descriptively. Question questionnaire and answer choice can be seen in Tables 2 and 3 .

Table 2. Preventative Action Question [19]

\begin{tabular}{|c|c|c|}
\hline Question & $\begin{array}{c}\text { Respondent's } \\
\text { Willingness }\end{array}$ & Answer Options \\
\hline \multirow{8}{*}{$\begin{array}{l}\text { Are you } \\
\text { willing to } \\
\text { implement } \\
\text { preventative } \\
\text { advice to } \\
\text { avoid } \\
\text { accidents on } \\
\text { mountain } \\
\text { climbing } \\
\text { activities? }\end{array}$} & \multirow{4}{*}{$\begin{array}{l}\text { Why are you } \\
\text { willing to } \\
\text { implement } \\
\text { preventative } \\
\text { suggestions? } \\
\text { (Choose two } \\
\text { answers) }\end{array}$} & $\begin{array}{l}\text { A. Accidents that occur } \\
\text { in ascent are very } \\
\text { serious }\end{array}$ \\
\hline & & $\begin{array}{l}\text { B. I feel responsible for } \\
\text { my own safety }\end{array}$ \\
\hline & & C. I think I have a risk \\
\hline & & $\begin{array}{l}\text { D. I want to prevent } \\
\text { accidents }\end{array}$ \\
\hline & \multirow{4}{*}{$\begin{array}{l}\text { Why are you } \\
\text { unwilling to } \\
\text { implement } \\
\text { preventative } \\
\text { suggestions? } \\
\text { (Choose two } \\
\text { answers) }\end{array}$} & $\begin{array}{l}\text { A. Accidents that occur } \\
\text { in the climb is not too } \\
\text { serious }\end{array}$ \\
\hline & & $\begin{array}{l}\text { B. I am not worried } \\
\text { about self-safety }\end{array}$ \\
\hline & & $\begin{array}{l}\text { C. I thought I had no } \\
\text { risk }\end{array}$ \\
\hline & & $\begin{array}{l}\text { D. I do not want to } \\
\text { prevent accidents }\end{array}$ \\
\hline
\end{tabular}

Table 3. Information Needs Question [19]

\begin{tabular}{|l|l|}
\hline \multicolumn{1}{|c|}{ Question } & \multicolumn{1}{c|}{ Answer Options } \\
\hline \multirow{4}{*}{$\begin{array}{l}\text { Based on the } \\
\text { perception between } \\
\text { men and women, } \\
\text { what information } \\
\text { do you want to } \\
\text { receive right now? } \\
\text { (Choose three }\end{array}$} & $\begin{array}{l}\text { A. What is the risk perception of } \\
\text { mountain climbing that is owned by } \\
\text { male and female climbers? }\end{array}$ \\
\cline { 2 - 2 } $\begin{array}{l}\text { answers }) \\
\text { B. Explain in detail the factors that } \\
\text { cause accidents in the ascent! }\end{array}$ & $\begin{array}{l}\text { C. What types of accident that occur } \\
\text { in the ascent? }\end{array}$ \\
\cline { 2 - 2 } & $\begin{array}{l}\text { D. What actions can prevent accidents } \\
\text { in climbing? }\end{array}$ \\
\hline
\end{tabular}

The Delphi method is used to make recommendations based on the opinion of experts who have expertise in mountain climbing and risk perceptions. The question posed to the expert for this recommendation was about the actions that the climber must take to be aware of the risks. Experts who advise recommendations for risk awareness on mountain climbing activities are:

1. Chairman of the Nature Lovers Student (WAPEALA) UNDIP

2. Secretary of Nature Lovers Student (WAPEALA) UNDIP

3. Lecturer of Social Psychology UNDIP

\section{Result and discussion}

The result of Kruskal-Wallis test for risk perception variable stated that $P$ value $(0.019)<$ critical area $(0,05)$. So, it can be concluded that there is a significant difference in risk perception between men and women.

From the results of data processing, it can be concluded that the perception of men included in the level of perception of low risk because most respondents 
feel a serious risk of and have the possibility of an accident. While women have a high perception of risk because most of the female respondents feel a very serious risk, as well as a lot of anxiety and distress. The statement is supported by the study of Short, et al. [3] which explains that men and women have different perceptions of risk as a whole. Men perceive lower risk than women in sports.

Data showed that female climb only once a year and male climb more than five times a year. The recapitulation can be seen descriptively in Table 4 .

Table 4. Climbing frequency

\begin{tabular}{|l|l|l|}
\hline \multirow{4}{*}{ Gender } & $\begin{array}{c}\text { Climbing } \\
\text { frequency per year }\end{array}$ & \multicolumn{1}{l}{ Total } \\
\hline \multirow{4}{*}{ Male } & once & 23 \\
\cline { 2 - 3 } & Two times & 23 \\
\cline { 2 - 3 } & Three times & 12 \\
\cline { 2 - 3 } & Four times & 15 \\
\cline { 2 - 3 } & Fefive times & 27 \\
\cline { 2 - 3 } & Total & 100 \\
\hline \multirow{5}{*}{} & once & 37 \\
\cline { 2 - 3 } & Two times & 28 \\
\cline { 2 - 3 } & Three times & 18 \\
\cline { 2 - 3 } & Four times & 13 \\
\cline { 2 - 3 } & >five times & 4 \\
\cline { 2 - 3 } & Total & \\
\hline
\end{tabular}

Self-concept theory can explain other causes related to differences in risk perceptions. Individuals differ in the degree to which they understand themselves as masculine or feminine. Based on gender theory, men are referred to as masculine individuals, where highly masculine individuals believe they have many attributes, interests, preferences and skills that the community usually associates with masculinity. While women are referred to as very feminine individuals, where very feminine individuals believe they have attributes, interests, preferences, and skills associated with femininity. In addition, self-esteem can also affect men in taking risks in every action taken. Self-esteem is how people judge the dimensions of psychological masculinity. So men tend to have high self-esteem compared to women in terms of independence, assertiveness and competence [201].

In another study conducted by Harris \& Jenkins [16], it was explained that the assessment of male risk was significantly seen from the severity of the injury suffered, while women assessed a risk of susceptibility to any type of injury. This suggests that women may avoid risky situations that cause injury and men may avoid risky situations only if the injury suffered has been severe. Almost everyone understands and realizes that outdoor activities such as mountain climbing have various risks. It also often heard that there was much news about accidents that occur on the climb but climber still does the activity. This fact is in line with the results of questionnaires that have been distributed to 200 respondents consisting of 100 male mountain climber respondents and 100 female mountain climbers. As many as $99 \%$ of all respondents claimed that they had known the news of the accident, and $98 \%$ of the respondents said still climbing the mountain despite an accident report. So it can be concluded that climbers still often ignore the risks that exist in mountain climbing.

According to Voeten [19], the relationship between perceptions of risk to preventive action questions can be seen from the willingness of respondents to carry out preventive measures and the belief that such precautions are effective in reducing accidents. If respondents are not willing to implement prevention and doubt the effectiveness of these preventive measures, then the respondent can have a high-risk perception. The relationship between the results of risk perception with the question of information needs can be seen from the information requirement. If the respondent does not require any more information, then it can be said the risk perception of the respondent is low, whereas if the respondent needs information about the factors - cause factors accidents, actions that can prevent accidents, it can be said respondents have a high-risk perception [19].

The results of this study indicate that the perception of men's risk is lower than that of women. The Delphi method is used to make recommendations in the opinion of experts who have expertise in mountain climbing and risk perceptions. Experts who advise recommendations for risks awareness of climbers on mountain climbing activities are the Chairman of the Nature Lovers Student (WAPEALA) UNDIP, UNDIP Nature Student Secretary (WAPEALA), and UNDIP Social Psychology Lecturer. The purpose of this recommendation is to raise the awareness of male climbers of a risk present in mountain climbing activities.

The Delphi method result suggests some recommendation to improve awareness of risks in mountain climbing activities for male climbers such as:

1. Cultivate a positive mental attitude that grows from daily climbers such as not complaining, positive thinking, not arrogant and humble. In addition, increasing the desire to live or will to live on male climbers.

2. Understand the risks that exist in nature, so climbers get a clear picture of the true risks in mountaineering activity.

3. Conduct the Cognitive Behavioral Therapy to raise awareness of personal safety.

4. Follow a mountain climbing school such as the nature lovers club (Wanadri).

5. Having instructors who can provide lessons on outdoor activities no matter how good the male climber is.

\section{Conclusions}

The result of Kruskal-Wallis test for risk perception variable stated that $P$ value $(0.019)<$ critical area $(0.05)$. It showed that there was a significant difference of risk perception between man and woman. Based on the 
analysis, the perception of men's risk is lower than that of women in mountaineering activities. Based on the implementation of the Delphi method, the recommendations to increase risk awareness of male mountain climbers are growing a positive mental attitude that grows from daily climbers such as not complaining, positive thinking, not arrogant and humble. In addition, increasing the desire to live or will to live on male climbers and showing the risks that exist in nature to get a clear picture of the true risks in mountain climbing can be conducted. Besides, performing Cognitive Behavior Therapy to awake awareness of self-salvation, following the school of mountaineers (for example Wanadri), having an instructor who can give lessons on outdoor activities can improve the awareness of the mountaineer, as well.

\section{References}

1. B. Soule, B. Lefevre, E. Boutroy, V. Reynier, F. Roux and J. Corneloup. Accidentology of mountain sports: Situation review \& diagnosis. PETZL Foundation, 1-47. (2014).

2. A. Chamarro And J. F. Castro. Accident Analysis and Prevention, 197-201. (2009).

3. S. E. Short, J. Reuter, J, Brandt and M.W. Short. The Online Journal of Sport Psychology, Vol 6 Issue 3. 38-46. (2004)

4. S.B. Sitkin. and A.L. Pablo. Academy of Management Review, Vol. 17, No. 1. 9-38. (1992).

5. E.L. Vazquez. Environmental Management and Health, Vol. 12 Issue: 2. 122-133. (2001)

6. G.C. Dickson, L. Price, W.M. Maclaren and W.M. Stein. Journal of Health Organization and Management, 18(4-5): 308-320. (2004).

7. C. Martha, X. Sanchez and M. Goma-i-Freixanet, Psychology of Sport and Exercise, Vol 10. Issue 1. 193-200. (2009).
8. L. Kern, A. Geneau, S. Laforest, A. Dumas, B. Tremblay, C. Goulet. Safety Science, Vol 62. 370375. (2014).

9. G. Demirhan, H. Asci, M. Kangalgil. and O. Saracbasi, O. Hacettepe Journal of Sport Sciences, 25 (1). 11-22. (2014).

10. Sunaryo. Psikologi Untuk Keperawatan. Jakarta: EGC. (2004).

11. S.P. Robbins, and T.A Judge. Organizational Behavior Edition 15. New Jersey: Pearson Education. (2013).

12. A. Marcon, G., Nguyen, M. Rava, M. Braggion, M. Grassi and M.E. Zanolin. Science of the Total Environment, Vol. 527-528. 270-278. (2015)

13. J. Inouye. Risk Perception: Theories, Strategies, And Next Steps. National Safety Council, 1-12. (2014).

14. E. Monasterio. Wilderness \& Environmental Medicine, Vol 25 Issue 2. 1-6. (2014).

15. G. Pomfret. Tourism Management, Vol 27 issue 1. 113-123. (2006).

16. C.R. Harris and M. Jenkins. Judgment and Decision Making, Vol. 1 No. 1. 48-63. (2006).

17. H. Herdiansyah. Gender dalam Perspektif Psikologi. Jakarta: Salemba Humanika. (2016).

18. T.J. Gordon. The Delphi Method. London: Millenium. (1994).

19. H. Voeten. Standard questionnaire on risk perception of an infectious disease outbreak. Effective Communication In Outbreak Management for Europe, 1-10. (2015).

20. [20] S.E.Taylor, L.A Peplau and D.O Sears. Psikologi Sosial Edisi Kedua Belas. Jakarta: Kencana. (2009). 